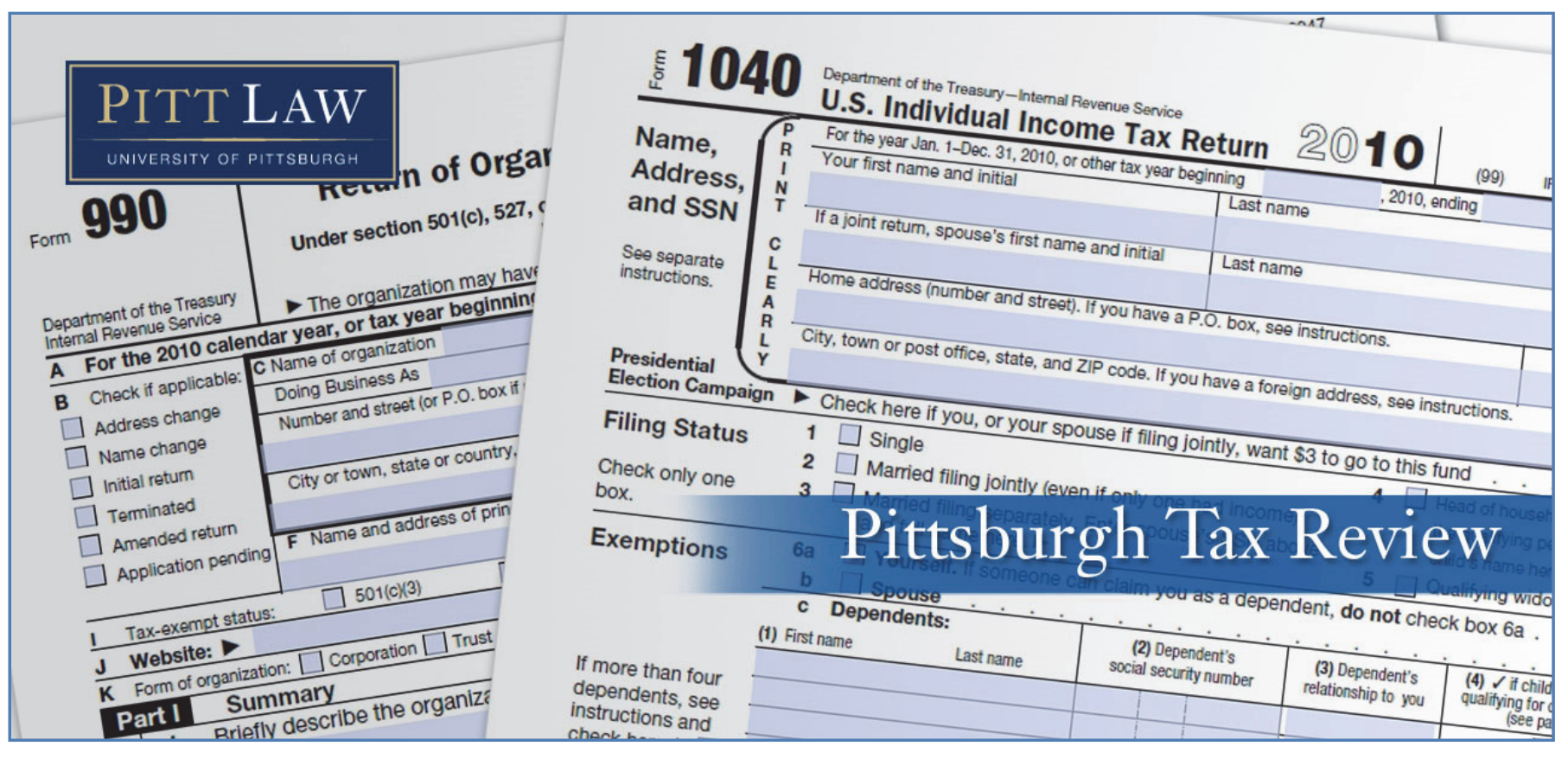

Volume 13 (2016) | ISSN 1932-1821 (print) 1932-1996 (online)

DOI 10.5195/taxreview.2016.48 | http://taxreview.law.pitt.edu

\title{
NOTE
}

THE TAX TREATMENT OF DAMAGES UNDER THE FALSE CLAIMS $A C T$ : AN UNSETTLED ISSUE

John Oliver Marron

\section{(cc) EY-NO-ND}

This work is licensed under a Creative Commons Attribution-Noncommercial-No Derivative Works 3.0 United States License.

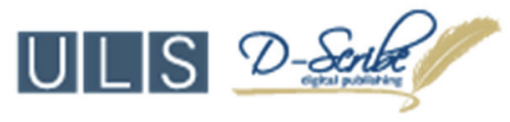

This journal is published by the University Library System of the University of Pittsburgh as part of its D-Scribe Digital Publishing Program, and is cosponsored by the University of Pittsburgh Press. 


\title{
NOTE
}

\section{THE TAX TREATMENT OF DAMAGES UNDER THE FALSE CLAIMS $A C T$ : AN UNSETTLED ISSUE}

\author{
John Oliver Marron ${ }^{*}$
}

Questions of characterization can often be overlooked when navigating through the complexities of our modern tax law and may become a pitfall for the unwary. A lack of clarity towards characterization has the potential to create highly litigated areas within our law that could put additional burdens upon judicial resources. The characterization of settlement payments arising under the False Claims Act has the potential to create such a problem. However, by adopting a predictable framework, this problem may be avoided.

This note focuses upon the tax characterization issues that have arisen in regards to the interpretation of damages in settlement agreements arising from violations of the False Claims Act ("FCA"). A potential circuit split has emerged over the method the courts should employ to determine the tax characterization of damages in the FCA settlement agreements. The emergence of this split is a result of two pervasive problems with the statutory scheme of the FCA: (1) there is no clear framework that may be used to determine the tax characterization of damages; and (2) it provides no real indication or clear definition as to what actually comprises the government's single damages.

This lack of clarity has caused courts much frustration over the years when analyzing the tax consequences of damages assessed to violators of the

\footnotetext{
* J.D. Candidate, University of Pittsburgh School of Law, 2016. I would like to thank Professor Anthony Infanti, Professor Danshera Cords, and the editorial staff of the Pittsburgh Tax Review for their guidance and support in preparing this Note for publication. I would also like to thank my friend and mentor the late Dr. James V. Jordan for all the kind words of encouragement and motivation that you have provided me throughout the years. While I am disheartened that you have departed from us, I find solace in knowing that you would be proud.
}

Pitt Tax Review | ISSN 1932-1821 (print) 1932-1996 (online)

DOI 10.5195/taxreview.2016.48 | http://taxreview.law.pitt.edu 


\section{4 |Pittsburgh Tax Review | Vol. 132016}

FCA. The frustration of the FCA is largely due to a few main reasons: (1) the FCA has been subject to considerable legislative changes over the years; (2) the FCA is both punitive and remedial in nature; and (3) the damages of the FCA have not been interpreted in a way that provides predictability to the outcomes of any particular case.

This note will begin with an introduction to the relevant statutory authority and a synopsis of the FCA's history. Next, there will be a discussion of the facts of the cases involved in the potential circuit split. These cases will illustrate that the lack of any definition as to what constitutes the government's single damages will provide further frustration under either precedent. Finally, through an analysis of the legislative history of the FCA, the relevant judicial precedence, and the goals and aspirations of the Code, I will provide an argument for a more predictable framework to determine the tax characterization of FCA damages.

\section{RELEVANT PROVISIONS}

Section 162(a) of the Code provides that, in general, a taxpayer may deduct "ordinary and necessary expenses paid or incurred during the taxable year in carrying on a trade or business." " However, under $\S 162(\mathrm{f})$, "No deduction shall be allowed under subsection (a) for any fine or similar penalty paid to a government for the violation of any law.",

The Regulations define a "fine or similar penalty" as an amount that is "[p]aid as a result of a conviction or a plea of guilty or nolo contendere for a crime . . . in a criminal proceeding." A "fine or similar penalty" also includes amounts paid as a "civil penalty imposed by Federal, State, or local law" or that are paid as a settlement to the taxpayer's potential liability for civil or criminal penalties. ${ }^{5}$ The Regulations exclude from the definition of "fine or similar penalty" legal fees and expenses related to the defense of claims and

\footnotetext{
${ }^{1}$ I.R.C. $\S 162(a)(2016)$.

${ }^{2}$ I.R.C. $§ 162(f)$ (2016).

${ }^{3}$ Treas. Reg. § 1.162-21(b)(1)(i) (1975).

${ }^{4}$ Treas. Reg. § 1.162-21(b)(1)(ii) (1975).

${ }^{5}$ Treas. Reg. § 1.16-21(b)(1)(iii) (1975).
}

Pitt Tax Review | ISSN 1932-1821 (print) 1932-1996 (online) DOI 10.5195/taxreview.2016.48 | http://taxreview.law.pitt.edu 
compensatory damages that are paid to the government. ${ }^{6}$ The problem faced by courts in FCA settlements is determining what amount of the damages paid to the government represent compensatory damages that may be deductible and what amount represents punitive damages that are barred from being a deductible business expense.

The FCA provides that violators who submit false claims to the government are to pay a civil penalty between $\$ 5,000$ and $\$ 10,000{ }^{7}$ The civil penalty is assessed to the violator on a per-claim basis. ${ }^{8}$ The FCA provides that the violator pay " 3 times the amount of damages which the Government sustains because of the act of that person." The FCA allows for the court to reduce the treble damages to double damages if the violator furnishes information to the government and cooperates with the investigation. ${ }^{10} \mathrm{~A}$ major problem for the courts under this scheme of damages is determining the proper tax characterization of damages that exceed the single amount of damages suffered by the government. This issue has been most pervasive in the context of settlements that arise under the FCA.

\section{A HiSTORY OF FALSE CLAIMS}

The FCA has an interesting and storied past. President Abraham Lincoln signed the original rendition of the FCA into law in $1863 .{ }^{11}$ The purpose of the law was to combat against the rampant amounts of fraud perpetrated against the government by individuals during the Civil War. ${ }^{12}$ Some examples of the fraudulent conduct of individuals included gun powder

\footnotetext{
${ }^{6}$ Treas. Reg. § 1.162-21(b)(2) (1975).

${ }^{7} 31$ U.S.C. $\$ 3729(\mathrm{a})(1)(\mathrm{G})(2012)$. This penalty is adjusted for inflation by the Federal Civil Penalties Adjustment Act of 1990. Id.

${ }^{8}$ See U.S. ex rel. Marcus v. Hess, 317 U.S. 537, 552 (1943) (each of the fifty-six fraudulent contracts represented separate claims to which the civil penalty would be assessed), see also United States v. Bornstein, 423 U.S. 303, 313 (1976) (civil penalty was assessed for each of the three shipments containing falsely branded goods sent by a sub-contractor).

${ }^{9} 31$ U.S.C. $\S 3729(\mathrm{a})(1)(\mathrm{G})(2012)$.

${ }^{10} 31$ U.S.C. $\$ 3729(\mathrm{a})(2)(2012)$.

${ }^{11}$ S. REP. NO. 99-345, at 8 (1986).

${ }^{12} I d$.
}

Pitt Tax Review | ISSN 1932-1821 (print) 1932-1996 (online) DOI 10.5195/taxreview.2016.48 | http://taxreview.law.pitt.edu 


\section{6 |Pittsburgh Tax Review | Vol. 132016}

barrels sold to the government that were filled with saw dust, soldiers' boots manufactured from cardboard, and linens manufactured from old rags. ${ }^{13}$ Fraud was so rampant and egregious that the House of Representatives appointed a special committee of seven individuals to investigate numerous allegations and suspicions of fraud. ${ }^{14}$ Their report contained many other examples and testimonies including weapons manufacturers overcharging the government for firearms, ${ }^{15}$ contracts for cattle made at above market prices, ${ }^{16}$ and army supplies bought or requisitioned by quartermasters without any consideration to the pricing of competing goods. ${ }^{17}$

To effectively combat these fraudulent individuals, Congress included in the FCA what is known as a qui tam action. ${ }^{18}$ Qui tam is short form for "qui tam pro domino rege quam pro si ipso in hac parte sequitur," meaning, "who sues on behalf of the King as well for himself." 19 This type of action in a more modern vernacular is known as a "whistle-blower" action. ${ }^{20}$ Under this type of action, a person, referred to as a relator, is able to bring suit on the behalf of the government. ${ }^{21}$ The relator is compensated for uncovering and prosecuting the fraud with a reward comprised of a portion of the recovery made by the government. ${ }^{22}$

Under the FCA's original format, a violator would face several consequences as a result of their fraudulent misdealing. The violator would be required to pay the government a civil penalty of $\$ 2,000$ for each fraudulent action, double the amount of damages suffered by the government,

\footnotetext{
13 James B. Helmer, Jr., False Claims Act: Incentivizing Integrity for 150 Years for Rogues, Privateers, Parasites and Patriots, 81 U. CIN. L. REV. 1261, 1264 (2013).

${ }^{14}$ H.R. REP. NO. 2, at 1 (1861).

${ }^{15} \mathrm{Id}$. at 34 .

${ }^{16} I d$. at 68 .

${ }^{17} I d$. at 53 .

${ }^{18}$ Helmer, supra note 13, at 1262.

${ }^{19} I d$.

${ }^{20}$ Mary Thompson \& Michael D. Siemer, Qui Tam Litigation: Pursuing Public Claims for Private Gain Under the Federal False Claims Act, 37 Hous. LAw. 18, 18 (2000).

${ }^{21}$ Helmer, supra note 13, at 1262; Thompson \& Siemer, supra note 20, at 18.

${ }^{22} \mathrm{Id}$.
}

Pitt Tax Review | ISSN 1932-1821 (print) 1932-1996 (online) DOI 10.5195/taxreview.2016.48 | http://taxreview.law.pitt.edu 
and the costs of suit. ${ }^{23}$ The violator faced criminal penalties as well: one to five year imprisonments or a $\$ 1,000$ to $\$ 5,000$ fine. ${ }^{24}$ The original act permitted the relator who brought the action to receive half of the damages collected by the government. ${ }^{25}$ Thus, the double damages in the original act were primarily to ensure that the government would be fully compensated. ${ }^{26}$ The bill was considered a success and achieved the goal of reducing fraud upon the government. ${ }^{27}$

The qui tam provisions of the original act faced much scrutiny during the World War II era. With a Department of Justice and a Federal Bureau of Investigation, the government was better equipped to combat against fraud and had a reduced need for assistance of insiders; as a result, the Attorney General would generally not prosecute cases under the civil provisions of the FCA. ${ }^{28}$ The neglect to prosecute fraudulent claims under the FCA gave enterprising individuals the ability to monitor courthouses for criminal indictments of fraud and subsequently bring a "parasitic lawsuit" under the FCA. ${ }^{29}$ Much debate focused over whether the qui tam provisions should be eliminated. The FCA, in effect, was ultimately rendered ineffective as a fraud prevention tool, since the amendments passed in 1943 severely reduced the recovery of a relator and provided that if the government had any knowledge of the fraud, the qui tam action would be dismissed. ${ }^{30}$

In the $1980 \mathrm{~s}$, the massive amounts of government spending by the Department of Defense created irresistible and numerous opportunities to cheat the government. ${ }^{31}$ Congress found that the amount of fraud being

${ }^{23}$ Act of March 2, 1863, ch. 67, 12 Stat. 696, 698 (1863) (codified as amended at 31 U.S.C. $\S 3730(d))$.

${ }^{24} \mathrm{Id}$.

${ }^{25} \mathrm{Id}$.

${ }^{26}$ Helmer, supra note 13, at 1266.

${ }^{27} I d$. at 1267.

${ }^{28} I d$.

${ }^{29} \mathrm{Id}$.

${ }^{30} I d$. at 1270.

${ }^{31} \mathrm{Id}$. at 1271.

Pitt Tax Review | ISSN 1932-1821 (print) 1932-1996 (online) DOI 10.5195/taxreview.2016.48 | http://taxreview.law.pitt.edu 


\section{8 | Pittsburgh Tax Review | Vol. 132016}

perpetrated by government contractors required the re-emergence of the FCA. ${ }^{32}$ The evidence showed that fraud against the government was on the rise. The Department of Justice estimated that fraud was draining anywhere from one to ten percent of the federal budget. ${ }^{33}$ With the budget being approximately one trillion dollars in 1985, this would result in between one to ten billion dollars of annual waste due to fraud. ${ }^{34}$ Furthermore, the Government Accounting Office determined in a 1981 study that "most fraud goes undetected due to the failure of Governmental agencies to effectively ensure accountability on the part of program recipients and Government contractors." 35 The Legislature recognized that a major problem facing the government was the lack of sufficient resources to effectively police fraud. ${ }^{36}$

In response to these findings, the government made significant changes to the damage and qui tam provisions of the FCA. The 1986 amendments provided that the civil penalty would be increased from $\$ 2,000$ to between $\$ 5,000$ and $\$ 10,000$ per claim. ${ }^{37}$ The revamped act also increased the amount of damages the government would receive from double to treble damages. Double damages would still be allowed in the case of cooperative defendants. ${ }^{38}$ The award to a qui tam plaintiff would vary depending upon whether the government prosecuted the action and if the relator provided valuable information to the case. If the government proceeded in the prosecution of the case, the relator may be awarded between 15 to $25 \%$ of the damages recovered, dependent upon the substantiality of the information

\footnotetext{
${ }^{32}$ Helmer, supra note 13, at 1272.

${ }^{33}$ S. REP. NO. 99-345, at 3 (1986).

${ }^{34} \mathrm{Id}$.

${ }^{35} \mathrm{Id}$.

${ }^{36} I d$. at 7.

${ }^{37}$ False Claims Act of 1986, Pub. L. No. 99-562, 100 Stat. 3153 (codified as amended at 31 U.S.C. $\S \S 3729-33)$ (1994). Congress increased this penalty to adjust for inflation. See H.R. REP. No. 99-660, at 20 (1986).

${ }^{38}$ False Claims Act of 1986, Pub. L. No. 99-562, 100 Stat. 3153 (codified as amended at 31 U.S.C. $\S \S 3729-33)$ (1994).
}

Pitt Tax Review | ISSN 1932-1821 (print) 1932-1996 (online) DOI 10.5195/taxreview.2016.48 | http://taxreview.law.pitt.edu 
provided. ${ }^{39}$ However, if the government does not proceed in the action, the relator may be awarded between 25 to $30 \%{ }^{40}$

\section{A. Talley and the Inquiry of Intent}

The case of Talley Industries, Inc. v. Commissioner originated when the government discovered that Stencel Aero Engineering Corp. ("Stencel"), a subsidiary of Talley Industries, Inc. ("Talley"), was fraudulently billing the government for work it completed under various contracts. ${ }^{41}$ A settlement agreement was reached between the United States, the Navy, Talley, and Stencel in which Talley agreed to pay $\$ 2.5$ million to the government. ${ }^{42}$ The government, based upon an audit, projected its actual losses to be $\$ 1.56$ million. ${ }^{43}$ The taxpayer deducted the full settlement payment of $\$ 2.5$ million for the tax year $1986 .^{44}$ The Commissioner argued that $\$ 940,000$ of the settlement payment was not deductible because it was intended to punish Talley, and therefore, constituted a fine or penalty pursuant to $\S 162(\mathrm{f})$ of the Code. ${ }^{45}$ The Tax Court, upon summary judgment, allowed the taxpayer to deduct the full $\$ 2.5$ million based upon a combined reading of United States v. Hess ${ }^{46}$ and United States v. Halper. ${ }^{47}$ Based upon those cases, the Tax Court reasoned that awards under the FCA were generally compensatory in

${ }^{39} \mathrm{Id}$.

${ }^{40} I d$. In some circumstances the relator may be limited to only $10 \%$ award. This will occur when a Court finds that the primary disclosures were from "specific information relating to allegations or transactions in a criminal, civil, or administrative hearing, in a congressional, administrative, or Government Accounting Office report, hearing, audit, or investigation, or from the news media." Id.

${ }^{41}$ Talley Indus., Inc. v. Comm'r, 116 F.3d 383, 384 (9th Cir. 1997).

${ }^{42} I d$. at 385 .

${ }^{43} \mathrm{Id}$. at 384 .

${ }^{44} I d$. at 385 .

${ }^{45} \mathrm{Id}$.

${ }^{46} 317$ U.S. 537 (1943).

${ }^{47} 490$ U.S. 435 (1989). See also Talley, 116 F.3d at 385-88.

Pitt Tax Review | ISSN 1932-1821 (print) 1932-1996 (online) DOI 10.5195/taxreview.2016.48 | http://taxreview.law.pitt.edu 
nature to the extent that they bear a rational relation to the government's actual losses. ${ }^{48}$

The Ninth Circuit adopted a different approach and reasoning upon appeal from the Tax Court. The court began its analysis upon the premise that the deductibility of a civil penalty would be dependent upon the purpose the penalty serves. ${ }^{49}$ If the purpose of the civil penalty were punitive, then the penalty would fall under $\S 162(\mathrm{f})$. However, if the purpose of the civil penalty were to compensate the government, then the penalty would be deductible. $^{50}$

Upon review of the facts, the court concluded that there was a genuine issue as to the nature and purpose of the $\$ 940,000$ payment. ${ }^{51}$ The court stated that the double damage provision of the FCA had both a punitive and a compensatory function ${ }^{52}$ and determined that the settlement agreement

${ }^{48}$ In Hess, the Supreme Court analyzed the damage provisions of the FCA to determine if they violated the Double Jeopardy Clause. The Court reasoned that chief purpose of the remedies in the FCA were not punitive in nature. U.S. ex rel. Marcus v. Hess, 317 U.S. 537, 551-52 (1943). The Court stated that it was clear the statute "was to provide for restitution to the government of money taken from it by fraud, and that the device of double damages plus a specific sum was chosen to make sure that the government would be made completely whole." Id. at 552. The Court went on to say that the decision was consistent with a single statement made by a Senator before the final passage of the Bill. Id. (citing ConG. GlOBE, 37Th CONG., 3D SeSS. 955 (1863)). But see Helmer, supra note 13, at 1265 (citing CONG. GloBe, 37TH CONG., 3D SESS. 955 (1863)) (another member of the Senate made strong statements that the purpose of the statute was to punish contractors). In Halper, the Supreme Court ruled that a civil award to the government bore no rational relationship to the Government's actual losses; therefore it was considered a punitive penalty. United States v. Halper, 490 U.S. 435, 449 (1989). The Tax Court reasoned that these two cases, read in tandem, stood for the notion that damages in a FCA case are generally compensatory if they bear a rational relationship to the government's actual losses. Talley Indus. v. Comm'r, 68 T.C.M. (CCH) 1412, 1994 T.C.M. (RIA) 9 94,608 (1994). Therefore, if one could rationally relate amounts of the payment to the government's actual losses, they could classify the damages as compensatory and thereby deduct the damages as "ordinary and necessary" expenses under § 162(a).

${ }^{49}$ Talley Indus. v. Comm'r, 116 F.3d 382, 385 (9th Cir. 1997).

${ }^{50} I d$. at $385-86$. Whether the penalty is deductible because it is defined as compensatory is questionable; the penalty should meet the test of $\S 162(a)$, being as "ordinary and necessary" expense, to properly be classified as deductible. In an early Tax Court decision which was essentially overruled by Congress with the passing of $\S 162(\mathrm{f})$, the Court stated that damages under the FCA would not meet the "ordinary and necessary" standard of § 162(a). See Faulk v. Comm'r, 26 T.C. 948, 950 (1956). The Court's analysis would lead one to believe that they consider compensatory damages automatically meet the "ordinary and necessary" requirement.

${ }^{51}$ Talley, 116 F.3d at 387.

${ }^{52} \mathrm{Id}$.

Pitt Tax Review | ISSN 1932-1821 (print) 1932-1996 (online)

DOI 10.5195/taxreview.2016.48 | http://taxreview.law.pitt.edu 
executed by the parties was ambiguous in regards to the nature of the $\$ 940,000$ payment. ${ }^{53}$ The Court remanded the case, instructing the trier of fact to make an inquiry as to the intent of the parties regarding the payment. ${ }^{54}$ The taxpayer would bear the burden of proving the intent of the payment. ${ }^{55}$

The intent-based test utilized in Talley does not give much guidance and leaves much to be desired. The First Circuit criticized the test, stating that the decision "offers an indistinct beacon by which to steer. The case is distinguishable on its facts and its message is unclear." ${ }^{.56}$ Others have criticized the intent-based test because intent is easily manipulated and almost impossible to police. ${ }^{57}$ The criticisms of the opinion seem appropriate; as there is no indication how future settlement payments should be treated. The only indicator that guides the parties is their intent. This is troubling given the fact that the Department of Justice had taken a strong stance that they refuse to characterize damages under FCA settlements for tax purposes. ${ }^{58}$ In fact, it is common practice for government agencies to pass the buck to the IRS when it comes to the characterization of settlement payments. ${ }^{59}$ Unfortunately, the IRS is usually not a party to the negotiations, leaving the tax issues to be ferreted out post-settlement. ${ }^{60}$

${ }^{53} I d$.

${ }^{54}$ Id. at $387-88$.

${ }^{55} \mathrm{Id}$. at 387 . Upon remand, the Tax Court looked extensively into the communications between the government and taxpayer. It found that the record showed there was no actual agreement and that the parties were silent as to the characterization of the $\$ 940,000$ portion of the damages. Talley Indus. v. Comm'r, 77 T.C.M. (CCH) 2191, 2196, 1999 T.C.M. (RIA) \99,200 (1999).

${ }^{56}$ Fresenius Med. Care Holdings, Inc. v. United States, 763 F.3d 64, 71 (1st Cir. 2014).

${ }^{57}$ John A. Bogdanski, Bad Guys Get Last Laugh-An Income Tax Deduction, 41 J. CoRP. TAX’N 27, 33 (2014). 2008).

${ }^{58}$ I.R.S. Industry Specialization Program Coordinated Issue 2008, WL 4106103, at 2 (Sept. 5,

${ }^{59}$ Abraham N.M. Shashy, Jr., Sara A. Silverstein \& Ariana F. Wallizada, Beyond Frustration: Section $162(f)$ and the Deductibility of Fines, Penalties, and Settlement Payments, 17 Fla. TAX ReV. 349, 360 (2015).

${ }^{60} \mathrm{Id}$. at 361.

Pitt Tax Review | ISSN 1932-1821 (print) 1932-1996 (online) DOI 10.5195/taxreview.2016.48 | http://taxreview.law.pitt.edu 


\section{2 |Pittsburgh Tax Review | Vol. 132016}

\section{$B$. Fresenius and the Economic Realities}

The First Circuit faced a nuanced problem in Fresenius Medical Care Holdings, Inc. v. United States. ${ }^{61}$ Fresenius Medical Care Holdings, Inc. ("Fresenius") entered into a number of complex criminal plea and civil settlement agreements with the government. ${ }^{62}$ The damages agreed upon totaled approximately $\$ 486$ million, of which $\$ 101$ million was to be for criminal fines and the remaining $\$ 385$ million for the civil liability under the FCA. ${ }^{63}$ The government and Fresenius agreed that $\$ 192.5$ million, the single damages, were compensatory damages and therefore deductible. ${ }^{64}$ The tax treatment of the remaining $\$ 192.5$ million was disputed. ${ }^{65}$ Fresenius contended and the government acquiesced that of the $\$ 192.5$ million in contention, the amount owed to the qui tam relators, \$66 million, was deductible because it was compensatory in nature. ${ }^{66}$

The district court in the course of the trial submitted the question to a jury that decided $\$ 95$ million of the contested amount was compensatory in nature, and therefore, deductible. ${ }^{67}$ The district court's charge to the jury was to measure the deductibility of the damages in terms of the economic realities while placing the burden of proof upon Fresenius. ${ }^{68}$ The government appealed the jury verdict and the First Circuit blessed the instructions that the court charged to the jury, noting that such an approach may be a departure

\footnotetext{
${ }^{61}$ This case is distinguishable from Talley in that it was initiated by whistleblowers who brought civil action claims under the FCA. Fresenius, 763 F.3d at 66 (1st Cir. 2014). The claims arose when a subsidiary that was acquired by Fresenius was found to be involved in fraudulent practices including, inter alia, engaging in double billing, fraudulent laboratory testing claims, and failures to report overpayments received by Medicare. $I d$.

${ }^{62} I d$.

${ }^{63} I d$. at 67 .

${ }^{64} I d$.

${ }^{65} \mathrm{Id}$.

${ }^{66} I d$.

${ }^{67}$ Fresenius, 763 F.3d at 67.

${ }^{68} \mathrm{Id}$. at 66.
}

Pitt Tax Review | ISSN 1932-1821 (print) 1932-1996 (online) DOI 10.5195/taxreview.2016.48 | http://taxreview.law.pitt.edu 
from the Ninth Circuit's treatment of the characterization of damages in Talley. ${ }^{69}$

An inquiry that focuses upon the economic realities elevates substance over form. As such, the intent of the parties would not be a controlling factor. The government argued an aggressive position that under Talley, courts should look only to the intent of the parties to determine the characterization of the payments, and that absent any intent to agree upon the characterization, the Court would have to overrule the jury verdict. ${ }^{70}$ In response to this argument the First Circuit stated that:

A rule that requires a tax characterization agreement as a precondition to deductibility focuses too single-mindedly on the parties' manifested intent in determining the tax treatment of a particular payment. Such an exclusive focus would give the government a whip hand of unprecedented ferocity: it could always defeat deductibility by the simple expedient of refusing to agree - no matter how arbitrarily - to the tax characterization of a payment. ${ }^{71}$

The First Circuit reasoned that many other inquiries into the interpretation of settle agreements generally do not rely upon the parties' manifested intent but look to the actual substance of dispute. ${ }^{72}$ However, the Court did limit a substantive inquiry to situations in which there was no actual agreement between the parties. ${ }^{73}$ The Court relied upon another tenet of tax law, that "amounts paid or received in settlement should receive the same tax treatment, to the extent practicable, as would have applied had the dispute been litigated and reduced to judgment.",74

While considering the economic realities of the agreements is a more useful test to determine the purpose of the payments, such a test is not of much use if there is no lens or framework to analyze the economic realities. For example, is it proper for the government to include actual damages, prejudgment interest, and any potential consequential damages in the

\footnotetext{
${ }^{69} I d$.

${ }^{70}$ Id. at $69-70$.

${ }^{71}$ Fresenius, 763 F.3d at 70.

${ }^{72}$ Id. But see infra note 99 , at 16.

${ }^{73} \mathrm{Id}$.

${ }^{74} I d$. at 71 .
}

Pitt Tax Review | ISSN 1932-1821 (print) 1932-1996 (online) DOI 10.5195/taxreview.2016.48 | http://taxreview.law.pitt.edu 


\section{4 |Pittsburgh Tax Review | Vol. 132016}

calculation of its single damages? Assuming the case did not involve a relator, if the government took such an approach, the economic realities of the transaction would reflect that the single damages are the only compensatory component of the settlement, and the remaining amounts of the treble damages would have to be classified as punitive. Further, it is inevitable with such a test that the court will have to consider the merits of the case outside of the context of the tax issues. ${ }^{75}$ Lastly, placing the determination of the tax characteristics to the discretion of a jury does little to create predictable outcomes in the future. ${ }^{76}$ Therefore, for the economic realities test to be most effective, the components of the government's damages must also be clarified.

The most useful insight of the Fresenius case comes from the district court's analysis of the FCA's damages provision. The court saw the Supreme Court's decision in Vermont Agency of Natural Resources v. United States ex rel. Stevens as a possible endorsement of a categorical approach to FCA damages, where the first third of the government's damages would be compensatory, the second third would be compensatory under United States v. Bornstein, and the last third would be punitive under Stevens.$^{77}$ However, the court believed that the Supreme Court's ruling in Cook County v. United States ex rel. Chandler showed an abandonment of this categorical approach. ${ }^{78}$ Based upon these decisions, the court determined that the damages under the FCA serve both a compensatory and punitive purpose and that purpose should be determined based upon the facts of any particular FCA litigation. ${ }^{79}$ While there is some lack of certainty from this approach, the district court's thorough analysis of the case law was a step in the right direction.

\footnotetext{
${ }^{75}$ Bogdanski, supra note 57, at 33.

${ }^{76} I d$.

${ }^{77}$ Fresenius Med. Care Holdings, Inc. v. United States, No. 08-12118-DPW, 2013 WL 1946216, at 5 (D. Mass. May 9, 2013).

${ }^{78}$ Id. at 13 .

${ }^{79} \mathrm{Id}$. at 14 .
}

Pitt Tax Review | ISSN 1932-1821 (print) 1932-1996 (online) DOI 10.5195/taxreview.2016.48 | http://taxreview.law.pitt.edu 


\section{A FRAMEWORK FOR DAMAGES}

Professor F. Phillip Manns provides a useful framework that courts have generally employed in a majority of cases when deciding whether civil sanctions are intended to be punitive.$^{80}$ The courts generally consider three factors: "(1) legislative intent, (2) the particular circumstances at hand, and (3) the nature of the remedy." ${ }^{\prime 11}$ To determine the legislative intent the courts will look to: "(1) legislative history; (2) the place of the provision in the statutory scheme; and (3) court decisions construing the provision at issue for purposes other than deductibility under section 162(f)." ${ }^{" 82}$ If the intent is ambiguous, after the first inquiry the courts will look to the "facts and circumstances specific to the case." ${ }^{~} 83$ If there is still a question as to intent, the final inquiry will be for the court to examine the "nature of the remedy available to the government upon proof of the claim." 84

The courts have generally followed this inquiry in FCA cases; however, a comprehensive and concrete framework has yet to develop. An examination of the FCA and its damages provision under this framework will give a clearer picture as to how the damage provisions should be characterized under section 162(f). Since the objective is to create a framework that will apply in all cases, the analysis will focus mostly upon the first step in the hierarchy suggested by Professor Manns.

\section{A. The Intent of Treble Damages}

There is no disputing that the original purpose of the FCA was to deter and prevent fraud upon the Government. Senator Henry Wilson, the original sponsor of the 1863 act, stated, "This bill is reported for the purpose of ferreting out and punishing these enormous frauds upon our Government." ${ }^{85}$

\footnotetext{
${ }^{80}$ F. Phillip Manns, Jr., Internal Revenue Code Section 162(f): When Does the Payment of Damages to a Government Punish the Payor?, 13 VA. TAX REV. 271, 288 (1993).

${ }^{81} I d$.

${ }^{82} I d$. at 289.

${ }^{83} \mathrm{Id}$.

${ }^{84} \mathrm{Id}$.

${ }^{85}$ See Helmer, supra note 13, at 1265, citing CONG. GLOBE, 37TH CONG., 3D SESS. 956 (1863).
}

Pitt Tax Review | ISSN 1932-1821 (print) 1932-1996 (online) DOI 10.5195/taxreview.2016.48 | http://taxreview.law.pitt.edu 


\section{6 |Pittsburgh Tax Review | Vol. 132016}

Senate Bill No. 467 was entitled a bill "to prevent and punish frauds upon the Government of the United States." $\$ 6$ The damage provisions under the original FCA contained a per-claim penalty and doubled the damages suffered by the government. The qui tam relator would be rewarded $50 \%$ of the Government's recovery under the original FCA. Therefore, the double damage provision was entirely remedial in nature and the per-claim penalty served a deterrent function.

The question that must be answered is whether Congress intended the treble damages provision of the 1986 amendments to the FCA to be remedial in nature or if there was intent for at least some portion of the treble damages to serve as an additional punishment. The treble damage provision of the FCA can reasonably be interpreted as serving both a remedial and punitive function because: (1) Congress intended the statute to be serve both a remedial and deterrent function; (2) courts that have interpreted the FCA in other contexts have found the statute to be both remedial and punitive; and (3) the economic realities of our modern time supports that interpretation.

Many of the proponents of the 1986 Amendments to the FCA emphasized the need to deter frauds upon the government. Senator Charles Grassley believed the increase in forfeitures under the revamped FCA would substantially increase the financial risks and demonstrate the Government's newfound resolve to stop fraud. ${ }^{87}$ Senator Dennis DeConcini of Arizona stressed in a prepared statement that the increased penalties and modifications to the qui tam provisions would increase the Government's ability to deter fraud. ${ }^{88}$ Congressman Jack Brooks of Texas, during floor debate, noted that the "increases in the penalties fixed in 1863 are needed to keep the deterrent value of the False Claims Act current and effective in our modern world." $" 89$ In the same floor debate, Congressman Hamilton Fish of

\footnotetext{
${ }^{86} \mathrm{Id}$.

${ }^{87}$ False Claims Reform Act: Hearing on S. 1562 Before the Subcomm. on Admin. Practice and Procedure of the S. Comm. on the Judiciary, 99th Cong. 3 (1985) (statement of Sen. Charles E. Grassley, Chairman, Subcommittee on Administrative Practice and Procedure) [hereinafter False Claims Reform Act].

${ }^{88} I d$. at 15.

${ }^{89} 132$ CONG. REC. 22,336 (1986) (statement of Con. Brooks).
}

Pitt Tax Review | ISSN 1932-1821 (print) 1932-1996 (online) DOI 10.5195/taxreview.2016.48 | http://taxreview.law.pitt.edu 
New York stressed that the "False Claims Act is remedial in nature." 90 However, the remedial nature of the statute was emphasized based upon concerns that the courts in the past had construed the FCA as being penal in nature. ${ }^{91}$ The concern for Congress had less to do with any tax concerns but more to do with what standard of intent courts would employ in FCA suits.

The most supportive statement to support a dual purpose occurred during floor debates in the House when Congressman Fish elaborated on the damages provisions stating:

while the False Claims Act is not a penal statute, it does have an important deterrent effect .... The double damages remedy has been a part of this law since 1863 and it implicitly contains a significant deterrence element. The double damages recovery, with the accompanying civil fine, is intended to be a substantial penalty to forcefully discourage individuals and companies that do business with the United States from engaging in fraudulent practices.... the dual purpose of any such law should always be to deter as well as punish fraudulent conduct. ${ }^{92}$

Both the House and Senate Reports submitted with the Bill stressed the deterrent and compensatory functions of the 1986 Amendments to the FCA. The Senate Report stated that the purpose of the Bill was to enhance the ability of the Government to "recover losses sustained as a result of fraud." 93 The report also indicates a need to "make the statute a more useful tool against fraud in modern times." 94 However, the report also states that a large reason that fraud upon the government is so pervasive is due to a lack of deterrence. ${ }^{95}$ The Government Accounting Office estimated that much fraud also goes undetected due to "weak internal controls" of the government and a failure to ensure accountability of government contractors. ${ }^{96}$ The fact that

${ }^{90} 132$ Cong. ReC. 22,336 (1986) (statement of Con. Fish). See also False Claims Reform Act, supra note 87 (statement of Jay B. Stephens, Deputy Associate Attorney General, U.S. Department of Justice) (the concern of the Department of Justice was that the treble damages would cause courts to view the FCA as penal in nature and impose a higher burden of proof).

${ }^{91} I d$.

${ }^{92}$ Id. at $22,336-37$.

${ }^{93}$ S. REP. No. 99-345, at 1 (1986).

${ }^{94} \mathrm{Id}$. at 2.

${ }^{95}$ See id. at 3.

${ }^{96} \mathrm{Id}$.

Pitt Tax Review | ISSN 1932-1821 (print) 1932-1996 (online) DOI 10.5195/taxreview.2016.48 | http://taxreview.law.pitt.edu 


\section{8 |Pittsburgh Tax Review | Vol. 132016}

most fraud goes undetected due to the inability of the government to police fraud makes it extremely important for the FCA to act as a deterrent to fraud. The House Report expressed similar concerns, stating that the FCA was being amended to "strengthen and clarify the government's ability to detect and prosecute civil fraud and to recoup damages suffered by the government as a result of such fraud." 997

The Supreme Court has yet to specifically rule on the proper tax characterization of FCA damages. However, the Court's interpretation of the FCA's damages in other contexts supports the conclusion that the damages provisions of the FCA are both remedial and punitive in nature. An examination of the relevant rulings will show that the Court's interpretation of the damages provisions has mirrored the legislative changes to the FCA.

We will first examine decisions that occurred prior to the enactment of the 1986 Amendments. In U.S. ex rel. Marcus v. Hess, the Supreme Court stated that the chief purpose of the FCA was: "to provide for restitution to the government of money taken from it by fraud, and that the device of double damages plus a specific sum was chosen to make sure that the government would be made completely whole." 98 This interpretation was echoed by the Court in United States v. Bornstein, that "Congress intended the double damages provision to play an important role in compensating the United States in cases where it has been defrauded." Inc. v. Comm'r, one of the more often-cited cases dealing with the FCA and deductibility, ${ }^{100}$ the Tax Court agreed that the chief purpose of the double damages clause of the FCA was to ensure that the Government be made "completely whole." 101 However, in the opinion, the Tax Court did allude to the possibility that the provisions may be partly punitive, stating it was

\footnotetext{
${ }^{97}$ H.R. REP. NO. 99-660, at 16 (1986).

${ }^{98}$ United States ex rel. Marcus v. Hess, 317 U.S. 537, 551-52 (1943).

${ }^{99}$ United States v. Bornstein, 423 U.S. 303, 314 (1976).

${ }^{100}$ See Shashy et al., supra note 59, at 385.

${ }^{101}$ Grossman \& Sons v. Comm'r, 48 T.C. 15, 31 (1967).
}

Pitt Tax Review | ISSN 1932-1821 (print) 1932-1996 (online) DOI 10.5195/taxreview.2016.48 | http://taxreview.law.pitt.edu 
possible that the public policy doctrine might apply and not every amount paid under the FCA may be deductible. ${ }^{102}$

From this line of cases, we can establish that the double damage provisions of the pre-1986 FCA were viewed mostly as compensatory in nature. This supports the original intent of the FCA as enacted in 1863. However, we see the beginning of a public policy exception lurking in the background in the Tax Court decision.

The Supreme Court cases of Stevens ${ }^{103}$ and Cook County ${ }^{104}$ show a shift in the way the Supreme Court viewed the multiple damages provisions in the FCA. In Stevens, the Court stated in its opinion that "the current version of the FCA imposes damages that are essentially punitive in nature." 105 The Court reasoned that the increase of the damages from double to treble damages showed that the provisions were punitive in nature, stating, "The very idea of treble damages reveals an intent to punish past, and to deter future, unlawful conduct." 106

The Court elaborated further in Cook County, stating, "While the tipping point between payback and punishment defies general formulation, being dependent on the workings of a particular statute and the course of particular litigation, the facts about the FCA show that the damages multiplier has compensatory traits along with the punitive." 107 The Court recognized that the punitive nature of the payments would depend upon the facts and

${ }^{102} I d$. The public policy doctrine was a precursor to the enactment of $\S 162(\mathrm{f})$. See Shashy et al., supra note 59, at 365 . Under the public policy doctrine the payment of fines were non-deductible when allowing those deductions would frustrate public policy and take the sting out of a fine or penalty. Id. Congress acted and codified this doctrine in 1969 by amending $\S 162$ (c) and enacting $\S 162(\mathrm{f})$. Id. at 366.

${ }^{103}$ In Stevens, the Supreme Court dealt with the issue of whether a relator could bring a qui tam action on behalf of the government against a State. Vt. Agency of Nat. Res. v. U.S. ex rel. Stevens, 529 U.S. 765 (2000). The Court ruled that individuals could not bring such a suit against a State because States were not considered "persons" under the FCA. Id. at 787-78.

${ }^{104}$ In Cook County, the question answered by the Supreme Court was whether a relator could bring suit on behalf of the government against a municipality. The Court ruled that municipal governments were "persons" who could be subject to a qui tam action. Cook Cnty. v. United States ex rel. Chandler, 538 U.S. 119, 120 (2003).

\footnotetext{
${ }^{105}$ Stevens, 529 U.S. at 784.

${ }^{106}$ Id. at 786 (quoting Tx. Indus. v. Radcliff Materials, 451 U.S. 630, 639 (1981)).

${ }^{107}$ Cook, 538 U.S. at 130.
}

Pitt Tax Review | ISSN 1932-1821 (print) 1932-1996 (online) DOI 10.5195/taxreview.2016.48 | http://taxreview.law.pitt.edu 


\section{0 | Pittsburgh Tax Review | Vol. 132016}

circumstances of each case. ${ }^{108}$ The Court gave recognition to the fact that the FCA had no mention of prejudgment interest or consequential damages, which would possibly, depending upon the circumstances, be a component of the government's compensatory damages. ${ }^{109}$ These decisions show a clear shift in the Court's treatment of multiple damages in the FCA that coincides with the legislative intent of the act.

The modern economics of our time also support a conclusion that the treble damages would serve a significant deterrent function in conjunction with the remedial function. Given the extensive amounts of fraud being perpetrated, it is debatable if the increase of the civil liability component from $\$ 2,000$ to $\$ 10,000$ per claim would be an adequate fraud prevention mechanism. While it is true that the per-claim penalty was increased to modernize and bring the penalty in line with inflation, ${ }^{110}$ this penalty is nominal if you compare it to the value of modern government contracts.

Consider one of the more egregious frauds perpetrated on the government in 1863: one unscrupulous contractor agreed to construct forts for the Government and managed to receive total advances of $\$ 171,000$ before the date the contract even began. ${ }^{111}$ On investigation, it was found that the majority of the contractor's estimates and prices were extremely inflated. ${ }^{112}$ Such a contract in 1863 would be considered a significant loss to the Government.

A contract of that size in today's dollars may be estimated to be approximately three million dollars. ${ }^{113}$ Now consider that Lockheed Martin, the highest compensated DOD Contractor in 2009, had a total contract value of approximately $\$ 31.9$ billion. ${ }^{114}$ The highest paid contracts in 1863 are dwarfed in comparison to the amount of remuneration contractors receive

\footnotetext{
${ }^{108} I d$.

${ }^{109}$ Id. at 131 .

${ }^{110}$ S. REP. NO. 99-345, at 17 (1986). See also H.R. REP. No. 99-660, at 17 (1986).

${ }^{111}$ H.R. REP. NO. 2, at 75 (1861).

${ }^{112} I d$. at 81 .

${ }^{113}$ Inflation Calculator, DAVEMANUEAL.COM, http://www.davemanueal.com/inflation-calculator .php (last visited Mar. 25, 2016).

${ }^{114}$ Jesse Ellman et al., Defense Contract Trends: U.S. Department of Defense Contract Spending and the Supporting Industrial Base, CSIS.ORG 27 (May 2011), http://csis.org/files/publication/ 110506_CSIS_Defense_Contract_Trends-sm2.pdf.
}

Pitt Tax Review | ISSN 1932-1821 (print) 1932-1996 (online) DOI 10.5195/taxreview.2016.48 | http://taxreview.law.pitt.edu 
from Government in our modern times. As such, a modestly increased perclaim civil penalty from $\$ 2,000$ to $\$ 10,000$ seems to be of little detriment to one who endeavors to defraud the Government. Arguably, as such, treble damages would serve as a greater deterrent than the civil penalty.

\section{B. What Constitutes Single Damages}

Even though the courts have been steadily clarifying the standards to which a payment will be considered punitive or compensatory, there is yet another potential future battleground. The difficult question that will have to be answered is: what actually constitutes the government's single damages under the FCA? The FCA simply states that the violator is liable for " 3 times the amount of damages which the Government sustains because of the act of that person." 115 However, the FCA does not define what constitutes damages under the Act. The damages will directly relate to the act of the violator, ${ }^{116}$ but what damages does the government sustain because of the act of that person? Is the prejudgment interest properly included in the single damage calculation since the loss of interest was sustained by government because of the "act of" the violator? The government may also have incurred consequential damages from the fraud. Should an estimation of the consequential damages also be included in the formulation of the government's calculation of single damages resulting from the "acts of" the violator?

On the face of the statute, there does not appear to be any limit to the damages the government may include in its calculation of single damages. The implications are that there may be increased liability to the violator as there is nothing that prevents the government arguing in the negotiation process that actual damages, prejudgment interest, and consequential damages are what comprise the single damage figure. If the government adopted such an approach, nearly all the amount of treble damages would be considered punitive because there is no basis to argue any of the payments were compensatory in nature.

However, based upon the legislative history of the 1986 Amendments of the FCA, I propose that the scope of the single damages should be limited

\footnotetext{
${ }^{115}$ I.R.C. $\S 3729(\mathrm{a})(1)(\mathrm{G})$.

${ }^{116} \mathrm{Id}$. at $\S 3729(\mathrm{a})$.
}

Pitt Tax Review | ISSN 1932-1821 (print) 1932-1996 (online) DOI 10.5195/taxreview.2016.48 | http://taxreview.law.pitt.edu 
to the damages directly linked to the fraudulent conduct. While one of the main purposes of the FCA was to deter fraudulent conduct, the treble damage provisions also appear to have a compensatory nature. The analysis of how prejudgment interest and consequential damages should be treated will support a conclusion that the single damages of the government should be limited to actual damages suffered by the acts of the violator.

\section{Prejudgment Interest}

The proper treatment of prejudgment interest under the FCA is to treat prejudgment interest as a component of the treble damages. While there is statutory authority for the Government to assess post judgment interest, ${ }^{117}$ there is no comparable statute that generally addresses the issue of prejudgment interest. ${ }^{118}$

Other sections of the U.S. Code specifically list prejudgment interest as a separate assessment upon an individual. For example, under Title 35, the U.S. Code provides that a claimant for the infringement of a patent may receive "damages adequate to compensate for the infringement ... together with interest and costs as fixed by the court." ${ }^{119}$ Under Title 15 the court may "award prejudgment interest on [treble damages] . . . beginning on the date of the service of claimant's pleadings setting forth a claim for such entry of judgment and ending on the date such entry is made."120

Since Congress did not specifically address interest under the FCA and elected to specifically address the treatment of prejudgment interest in other areas of the Code, the assumption should be that prejudgment interest would be a component of the Government's treble damages.

${ }^{117} 28$ U.S.C. $\$ 1961(\mathrm{c})$.

${ }^{118}$ Karl Oakes, 5 51:76: Right to Prejudgment Interest, Generally, in 21A FED. PROC., L. ED. (2008). The Debt Collection Act of 1982 provides some authority to collect interest on debts owed to the Government. Id. This statute would not properly apply to the context of FCA damages as it only applies to claims of the Government that arise from debt owed to the Government. Id. As such, the statute gives the Government the ability to collect interest on unpaid debt. Id. The Act also requires the Government to give notice to the debtor prior to assessing interest. $I d$.

11935 U.S.C. $\$ 284$ (2012).

${ }^{120} 15$ U.S.C. $\S 1117$ (2012).

Pitt Tax Review | ISSN 1932-1821 (print) 1932-1996 (online)

DOI 10.5195/taxreview.2016.48 | http://taxreview.law.pitt.edu 
Further, the Supreme Court noted that prejudgment interest is essential to the full compensation of the government and that the significant length of the statute of limitations of the FCA could lend prejudgment interest to being a significant part of the government's recovery. ${ }^{121}$ It is highly unlikely that Congress would not have addressed the treatment of prejudgment interest if they did not feel it was already adequately addressed by the treble damages provision.

\section{Consequential Damages}

The House and the Senate had originally drafted differing damage provisions in their respective Bills. The damage provision in H.R. 4827 as Reported on June 26, 1986, read as follows:

is liable to the United States Government for a civil penalty of not less than $\$ 5,000$ and not more than $\$ 10,000$, for an amount equal to consequential damages ... plus 2 times the amount of damages (other than such consequential damages) which the Government sustains because of the act of that person. ${ }^{122}$

The Senate Bill, S. 1562, as referred on August 15, 1986 increased the double damages to treble and damages and also contained a separate reference to consequential damages. ${ }^{123}$ However, the 1986 amendments to the FCA as passed on October 27, 1986 contained no similar separation of consequential damages from the trebled damages. ${ }^{124}$

The consequential damages may have initially been separated and explicitly stated in the FCA amendments due to concerns of the Department of Justice that there was "considerable confusion among the circuit courts as to whether or not consequential damages can be recovered in an action under the False Claims Act." 125 The DOJ further stated that many times the consequential damages in FCA cases would exceed the actual damages

\footnotetext{
${ }^{121}$ Cook, 538 U.S. at 131.

${ }^{122}$ H.R. REP. No. 99-660, pt. 7, at 3 (1986).

${ }^{123}$ S. REP. No. 1562, pt. 3, at 3 (1986).

${ }^{124}$ See False Claims Amendments Act of 1986, Pub. L. No. 99-562 (100 Stat. 3153).

${ }^{125}$ False Claims Act of 1979, S. 1981: Hearing Before the Subcomm. on Improvements in Judicial Machinery of the Comm. on the Judiciary United States Senate, 96 Cong. 3 (1979) (statement of Roger Edgar, Dir., Commercial Litig. Branch, Dep’t of Justice).
}

Pitt Tax Review | ISSN 1932-1821 (print) 1932-1996 (online) DOI 10.5195/taxreview.2016.48 | http://taxreview.law.pitt.edu 


\section{4 | Pittsburgh Tax Review | Vol. 132016}

sustained by the government. ${ }^{126}$ Congress most likely included consequential damages to alleviate these concerns. However, the consequential damages were removed from the FCA as a compromise between the House and the Senate. ${ }^{127}$ The compromise was essentially to agree to increase the double damages to treble damages to account for the government's potential consequential damages.

Since the treble damages were agreed to as a compromise for the elimination of the specific reference to consequential damages, it follows that consequential damages should be a compensatory component of the Government's treble damages.

Considering the all of the facts as set forth, the most appropriate treatment of damages under the FCA is that they be limited to the government's actual damages. There are strong arguments that the legislative history supports this inference due to the fact that prejudgment interest and consequential damages were most likely considered by the legislature to be components of the government's treble damage recovery.

\section{E. Passing Through the Doorway of 162(a)}

The final issue within our framework addresses a problem that exists in the First Circuit's analysis in Fresenius. In the opinion, the court stated that "[s]ingle damages are plainly compensatory and, thus, plainly deductible." 128 The court also reasoned "some amounts in excess of single damages generally are regarded as compensatory, and therefore deductible." 129 However, these conclusions are too broad as compensatory damages are not per se deductible. By a more technical application of the Code, the compensatory damages paid to the government will still have to meet the positive test as an "ordinary and necessary" business expense pursuant to $\S 162$ (a) before they can be properly characterized as a deductible business

\footnotetext{
${ }^{126} I d$.

${ }^{127} 132$ CONG. REC. 29,321 (1986) (statement of Con. Glickman).

${ }^{128}$ Fresenius, 763 F.3d at 68.

${ }^{129} \mathrm{Id}$.
}

Pitt Tax Review | ISSN 1932-1821 (print) 1932-1996 (online) DOI 10.5195/taxreview.2016.48 | http://taxreview.law.pitt.edu 
expense. This interpretation best reflects the overall scheme of the Code as well as the language used in the Treasury Regulations that pertain to $\S 162(\mathrm{f})$.

The Treasury Regulations for $\S 162$ give multiple examples illustrating when penalties are fines or compensatory. Amounts that are classified as compensatory in these examples are not said to be deductible under $\S 162$ (a). The examples only state that the amounts would not be precluded by $\S 162(\mathrm{f}){ }^{130}$ This language indicates that penalties being classified as compensatory are only precluded from the general exclusion of $\S 162(f)$. It does not follow that preclusion from $\S 162$ (f) means that the compensatory damages are deductible. All that is certain from these examples is that compensatory damages are not "fines or penalties." There is no Code section that specifically states that compensatory damages are deductible business expenses. Therefore, the compensatory damages must pass through the "ordinary and necessary" business expense test of $\S 162$ (a) to be properly characterized as a deductible business expense.

In most instances it should not be difficult for the compensatory damages to meet the test of $\S 162$ (a). However, there may be some instances where the compensatory damages are not properly cast as an ordinary and necessary business expense due to their nature or the surrounding facts and circumstances.

\section{CONCLUSION}

The treble damages under the FCA serve both a punitive and compensatory function. When courts decide upon the tax characteristics of settlement payments, the analysis should begin with a determination of the government's actual damages. Once the actual damages have been determined the amount should be tripled to give a benchmark of the total amount the government would be able to recover had the case been litigated.

The court should then consider what components of the treble damages are comprised of relator's fees, prejudgment interest, and consequential damages. The remaining amount of the treble damages will be properly characterized as punitive and non-deductible under 162(f) of the Code. Lastly, all compensatory damages should still be run through the "ordinary

${ }^{130}$ See Treas. Reg. § 1.162-21(c) (1975).

Pitt Tax Review | ISSN 1932-1821 (print) 1932-1996 (online) DOI 10.5195/taxreview.2016.48 | http://taxreview.law.pitt.edu 


\section{6 | Pittsburgh Tax Review | Vol. 132016}

and necessary" test of 162(a) before they are properly characterized as a deductible business expense.

Pitt Tax Review | ISSN 1932-1821 (print) 1932-1996 (online) DOI 10.5195/taxreview.2016.48 | http://taxreview.law.pitt.edu 